\author{
Bondar Ihor, \\ Associated Professor, \\ Honored Worker of Culture of Ukraine, \\ Kyiv National University of Culture and Arts \\ bondar_i.s.2018@i.ua \\ ORCID 0000-0001-8972-0941
}

\title{
DIFFERENTIATION OF COMPUTER-AIDED FORM-MAKING INTERPRETATIONS IN THE ARCHITECTURAL DESIGN OF POSTMODERNISM
}

\begin{abstract}
The purpose of the article is to specify the differentiated concepts of computer-aided form-making in the architectural design of postmodernism. Methodology. Within the frame of the tasks set the analysis and synthesis of scientific achievements of well-known scientists and world-renowned designers in architecture were conducted, methods of generalization and systematization of the research subject were used. Scientific novelty. A detailed explanation of computer-aided form-making in the architectural design of postmodernism is for the first time presented in this work. The notion of "hypersurface" is specified and extended. The role and place of the computer which is transformed into an element of the paradigmatic and synergetic reality by means of which the transfer of intelligence occurs are determined. Conclusions. As a result of the differentiation and analysis of the concepts of computer-aided form-making, applied in the architectural design of postmodernism, the following assumptions can be made: 1) the hypersurface is created as a space that does not divide, but rather encompasses, at the same time there is unification of the avant-garde and the ordinary system in the general human culture; 2) the computer originally being the proper factor of the design process as an exteriorly defined instrument of interpretation becomes a computer reality and acquires characteristics of paradigmatic and synergetic reality; 3) automation of thought takes place, with computers becoming its symbol; moreover, the transfer of intelligence to the systems occurs, and this is a question of the culture of creativity. It is impossible to get rid of it, but an architect or a designer still remains the creator and original source.
\end{abstract}

Key words: hypersurface, computer-aided form-making, architectural design, postmodernism.

Бондар Іеор Савич, доцент, заслужений працівник культури України, Київський національний університет культури і мистецтв

Диференціація трактувань комп'ютерного формотворення в архітектурному дизайні постмодернізму

Mema дослідження - деталізувати диференційовані поняття щодо комп'ютерного фрормотворення в архітектурному дизайні постмодернізму. Методи дослідження. У межах поставлених завдань було проведено аналіз та синтез наукових доробок dідомих науковців та дизайнерів в архітектурі, використані методи узагальнення та систематизації предмету дослідження. Наукова новизна. У роботі вперше представлено розгорнуте пояснення комп'ютерного формотворення в архітектурному дизайні постмодернізму. Деталізовані і поглиблені поняття «гіпероболонки». Визначено роль і місце комп'ютера, який перетворюється в елемент парадигмальної синергетичної реальності за допомоги якого відбувається перенесення інтелекту. Висновки. Отже, в результаті диференціації та аналізу понять комп'ютерного формотворення, що застосовуються в архітектурному дизайні постмодернізму, можна зробити наступні узагальнення: 1) гіпероболонка створюється як простір, який не розподіляє, а охоплює, при цьому відбувається єднання авангардної і звичайної системи в загальній людській культурі; 2) комп'ютер із належного чинника проектного процесу як екстеріорно визначеного засобу інтерпретації перетворюється в комп'ютерну реальність і набуває ознак парадигмальної синергетичної реальності; 3) відбувається автоматизація думки, символом котрої стають комп ютери, відбувається перенос інтелекту на системи і це питання культури творчості. Позбавитись цього неможливо, але творцем, першоджерелом залишається архітектор або дизайнер.

Ключові слова: гіпероболонка, комп'ютерне формотворення, архітектурний дизайн, постмодернізм.

Бондарь Игорь Савович, доцент, заслуженный работник культуры Украины, Киевский национальный университет культуры и искусств

Дифференциация трактовки компьютерного формообразования в архитектурном дизайне постмодернизма

Цель исследования - детализировать дифференцированные понятия по компьютерному формообразованию в архитектурном дизайне постмодернизма. Методы исследования. В рамках поставленных задач был проведен анализ и синтез научных разработок общеизвестных ученых и всемирно известных дизайнеров в архитектуре, использованы методы обобщения и систематизации предмета исследования. Научная новизна. В данной работе впервые представлено развернутое объяснение компьютерного формообразования в архитектурном дизайне постмодернизма. Детализировано и углублено понятие «гипероболочки». Определены роль и место компьютера который превращается в элемент парадигмальной синергетической реальности с помощью которого происходит перенос интеллекта. Выводы. Итак, в результате дифференциации и анализа понятий компьютерного формообразования, применяемые в архитектурном дизайне постмодернизма можно сделать следующие посылы: 1) гипероболочка создается как пространство, не распределяет, а охватывает, при этом происходит единение авангардной и обычной системы в общей человеческой культуре; 2) компьютер с надлежащего фактора проектного процесса как экстериорно определенного средства интерпретации превращается в компьютерную реальность и приобретает признаки парадигмальной синергетической реальности; 3) происходит автоматизация мысли, символом которой становятся компьютеры, происходит перенос интеллекта на системы и это вопрос культуры творчества. Избавиться от этого невозможно, но творцом, первоисточником остается архитектор или дизайнер.

Ключевые слова: гипероболочка, компьютерное формообразования, архитектурный дизайн, постмодернизм.

Introduction. Under the modern conditions of development of society information provision and tasks of computer-based form-making in the architectural design, there is a certain need to show the role of computer systems. We have identified a fairly narrow topic of explanations differentiation, but it is about how computer becomes a means of interpreting and explicating an image in architecture, a creative mechanism capable of being born when it transforms from being a means to a subject of discourse or a subject of architectural designing, interlocutor and a partner of the design process.

The purpose of the study. The purpose of the study is to analyze specific concepts by means of which computer explications of form-making in the architectural design of postmodernism take place. Achievement of this purpose involves solving the following tasks: 1) describe and deepen the concept of "hypersurface", which is

(c) Bondar I., 2019 
characteristic of postmodernism; 2) find out what changes and benefits are provided when using the computer in architecture; 3 ) determine the role and place of e-culture in architectural design.

Methodology and analysis of the source base. According to the tasks set, an analysis was conducted to determine how much the computer becomes a means of interpreting and explicating an image in architecture, a creative mechanism capable of being born when it transforms from being a means to a subject of discourse or a subject of architectural designing, interlocutor and a partner of the design process.

It is important to note that the cyberspace or computer screen becomes one of the important factors in the design process - one of the signs of an interpretive postmodernist paradigm. Stephen Perrella refers to the concept of "hypersurface" and explains the creation of a magical vision of architectural space [10]. I. Dobritsyna [2] noted that there is a transformation of the traditional form into a new energy of the image and forms. I.F. Ihnatieva [3] links reconstruction with a figurative transformation of the design. Yu. H. Lehenkyi $[4 ; 5]$ appeals to the production of a sensory reaction during transcoding in the process of creating material images. The authors of the publication "Aesthetic values of the subject-spatial environment" talk about a certain super-reality of modern architecture [9]. P.Virilio emphasizes the transfer of intelligence to systems that eventually became autonomous and marginalized [7]. M. Khasiieva [8] refers to the analysis of the industrial and informational society postmodernism concepts. K. Kurokawa determines the preconditions for the emergence of the concept. V.V. Avdieieva considers the architecture of postmodernism and its directions [1].

Results of the study. It is important to note that the cyberspace or computer screen becomes one of the important factors in the design process - one of the signs of an interpretive postmodernist paradigm. The computer exists as a means, an interpreter, ability to interpret the same genetic algorithm of populations or something else that becomes the subject of presentation, deformation, transformation, and transmutation as the final design process.

It is important that the computer brings the person closer to the universe and, at the same time, repels from the universe, because the computer language is the language of objectification, which Mykola Berdiaiev did not respect so much and which, to a certain extent, speaks of the exterior space, according to J. Deloza, not the interior. This is where it is necessary to start a campaign in the space of computer adequacies of reality, which cannot be exaggerated and cannot be considered prominent in the design. They play the role of a proper factor as an externally defined means of interpretation in the design process.

There appears an image of the so-called "electronic baroque". The computer creates redundant, super extreme conditions of reality vision that correlates with the reality of electronic visual practice. The form in this sense is a certain unpredictable construct, which depends on completely different circumstances: programming, programming language, programmer, artist, and architect. For example, S. Perrella, a well-known researcher of the "electronic baroque", an American architect, editor of the Newsline newspaper and a collection of research papers in the history of architecture at the Columbia University DSAP, is enthusiastic about studies of the relation of architecture to information. In a series of articles from 1998 to 1999, he looks at creating topological surfaces in architecture and proposes the concept of "hypersurface". The hypersurface is not a shell that occurs within the theoretical constructs of $\mathrm{O}$. Habrychevskyi, - no. This is not even a universal division of space. The hypersurface is created as a space that does not separate, but covers. After all, it is important to note that all this exercise of the hypersurface is associated with the fascination with the philosophical metaphors of postmodernism. S. Perrella believes that the philosophy of J. Derrida and G. Deleuze becomes that foundation upon which one can already determine the dimension of a radical return to nonlinear architecture, the movement from Euclidean to non-Euclidean geometry. The very return is seen as a visual image.

It's not that difficult. But this visual image with the help of computer technology turns into a sort of team of propagandists or campaigning mass production that has its own character. The viewer himself can create unforeseen architectural forms using a computer. Computers make it possible to do it in front of the audience. Yes, there is a real Guggenheim Museum in Bilbao, but there is also a virtual version implemented by the architects of the Asymptote group, Hanie Rashid and Lize en Cur. When we look at all of these products, they look rather strange.

The first thing to note is technomorphic determinism. Secondly, it is not designed objects of architecture, but the design of industrial forms. Technomorphism in the context of virtual adequacy becomes a very aggressive toy. The aesthetics of technomorphic space itself is aggressively superfluous. S. Perrella expresses dissatisfaction with the fact that most of the new projects, as well as their implementation, are connected with modernism, that is, with the deep metaphysical origins of architectural creativity. He would like to see more relaxed and unexpected realities that depend on consumer strategies, from interactive, subjectivist and other radically-minded means of vision.

We can say that this transformation of the reality of architecture tends to post-classical means of understanding the architecture itself, which is understood as a hypersurface, as something that crosses space. But for some reason, this space is perceived as a form or mass. Moreover, this space is perceived as a technomorphic configuration. If we try to ask why it is so, nobody will answer. It seems that this is a relapse of technomorphic thinking of the classics or modern in the broad sense. However, this is not quite the case.

Let's turn to the virtual projects already mentioned by us. Works such as Marcos Novak's "Trace of Rays" from the "Worlds of Progression" series, a permanent visual installation, "hypersurface", an interactive virtual installation, 1995, 1998, are also largely a kind of visual transmission of technomorphism. Almost everything changes, but the configuration, technomorphic design is dramatically defined as the infinite, continuous space of architecture.

S. Perrella`s work "Hypersurface", a computer experiment with a topological architectural form, 1990, a 
project that was worked out together with the Institute of Electronic Methods of Structural Sheeting, suggests that technopopulations are as aggressive as the destruction of forms itself. Design objects of architecture cannot exist in this context - it is rather designed as visual adequacy, future design.

S. Perrella also creates more visual optical realities, such as "Hypersurface", haptic horizons, 1995, using techniques of modern cinema in architecture [10]. Consequently, this is to a large extent an optical and, moreover, a hyperopticum that does not require any comment. The project is neither architectural nor artistic, nor cinematic, but screen-imaging, where the screen imaging, if not fascinates, creates a space of magic vision of the architectural space.

In the end,Athere comes the era of surfaces with regular geometric constants that do not have any cultural context. Haresh Lalvani's projects "Projects of the 1980s and 1990s" are hypersurfaces of purely geometric type, obviously, to the extent that the program's reality of this project lacks of prospects. It cannot even be defined either in the space of geometry or in the space of architecture. But it is meant as a visual agency.

The hypersurface "Wave Splice" was patented in 1996. This is already a reality that can be patented, because it is completely technomorphic and belongs to a technomorphic space in which mechanical determinism is defined as an absolute complete and installed destruction of classical culture. This is a post-classical space that refers to biomorphic analogs, but they, again, are projected onto a technomorphic basis. This technomorphism is impossible to get rid of - it exists as a dominant.

All the works of the visualists of the screen, especially the work by Marcos Novak "Form V4D", a virtual experiment and merging of technological and biological forms, 2001, suggests that the forms resemble a transcript of unreality - these are certain subconscious immersions in the world of predators or technomorph populations that have come from "distant worlds" - the works by José David Alfaro Siqueiros, José Clemente Orozco. All the works that we see in the computer performance are similar to technomorphic depiction of reality. Strange though it might sound, the computer does not give birth to anything new. It does not allow to form Leonardo and does not give knowledge of the anatomy of Michelangelo, does not give the huge horizons of light of the Middle Ages, it gives only mechanic and deterministic configurations that an "artist-designer" can incarnate, embody or imprint in the space of the graphic image.

The artist is engaged in decomposing the system or archetype and tries to deconstruct the shape in general. In addition, he shows an image, understanding it quite widely, as something that arises in the artist's imagination, something that symbolizes the consistency of a figurative configuration in the depths of the visual culture. The architectural form has not known this kind of double deconstruction of the image yet. This leads to a kind of energetic image of the hypersurface. However, there are hypersurfaces of figurative shape, which resemble an explosion over the abyss. Eventually, an event that resembles a special way of deconstructing the traditional image appears, as well as the traditional form and transforming them into a new energy of the image and forms [2].

"It seems that the concept of the hypersurface leads the author to the idea that there is a system capable of self-reproduction, which is deep enough in architecture and culture. This moment is typical like the intrigue of repetition of all possible practices, all these forces strive outwards and today they already challenge and threaten the authorship of the designer," - I. Dobritsyna notes [2, 289].

One can say that this is an exaggeration, it is impossible to deconstruct both the image and the material constructions together. Deconstruction as such is a figurative transformation of a design. But if we unfold it, we distribute it on two levels and try to talk about a separate figurative deconstruction and a separate constructive deconstruction, then, in fact, we get into the realm of design [3]. Design occurs when the image prompts the search for real construction equivalents. After all, there is a completely different problem: intervention of a virtual agent, detached from its material substrate. That is, the computer image exists on its own, and then it can somehow correlate with one or another material substructure.

After all, any visual agency, basing on synesthesia, still carries the deep code of re-coding of visual receptions into a tactile language, presents conformity to the material substrate, no matter if we want it or not $[4 ; 5]$. Therefore, it is impossible to separate the ideal from the material. And it is exactly what the theoreticians of contemporary design or modern architecture are trying to do. Deleuze did not succeed in it either no matter how hard he tried to oppose the substructure, which he calls the fold, to the material substrate. It is important to note that design never destroys real worlds, never violates their foundations of materiality, and does not try to break away into that ferocious distance, which is linked with the ideal dimension of the image. The image-model, image-thing or imageconfiguration that are read as a space of human existence, become a priority in the form-making of design objects of architecture.

Electronic media are becoming the main interlocutor of the communicative process. E-culture is shifting values and aggressive consumption is becoming a simple and accessible mechanism of interaction. S. Perrella, like many other representatives of the "electronic baroque", is obsessed with the search for alternative principles of architectural form-making. Perrella created many works of the "electronic baroque", which demonstrates not just the enthusiasm, but a certain strategy of figurative reality determination, which preceded the constructive principles of architecture.

The image in digital media gets discretization, becomes a definite dimensional structure and converges to metaphysical grounds, to mathematical models - the genetic algorithm. Thus, there arises the hyperspace and the hypersurface, which somehow constructs as a super construct or some super-reality of modern architecture. Researchers are trying to develop the differentiation of the hypersurface, as nothing new has been proposed 
besides Gestalt psychology or topological models of the field [9]. The hypersurface is born in problematic situations that arise when opposing entities suddenly enter into close union and no longer withstand isolation - neither linguistic nor mathematical.

That is, the hypersurface becomes the ascending constructor, which gives the opportunity to move in space not only through the division of space but also through its embracing, breakdown, and understanding. This construct would not be considered strange, but the interpretive space suggests that it arises exactly as a visual agency, and then pseudopopulations of such hypersurfaces appear from it and create the discourse of the project architecture existence. It seems to exist and does not exist.

S. Perrella states: "Hypersurface can be considered as an effect of uniting two still incommensurable, unmatched trajectories of culture, which arise suddenly, somewhere from inside of the interface. We mean the connection of the trajectories of high aesthetic culture, in which there is an academic discourse of architecture with the trajectories of cultural creativity, bearing the symbols of everyday consumption, separated from it. Improvisations and an increase in dichotomy for the sake of argumentation are united here. The concept of the hypersurface is an attempt to determine the nature of the union of two completely different systems - the avant-garde and the ordinary ones that occupy the place of two fundamentally different spatial systems in the general human culture. Each of the systems tries to reach the surface of the architectural construction" [10, 10].

We can assume that this manifesto is an excessive escalation and exalted apologetics of the hypersurface. The hypersurface, like the suprematism of Kazymyr Malevych, like a general architectural or design pattern, cannot exist as the world generated only by the mass media. It seems impossible to combine the interconnected things, but it is combined in the cyberspace, in the space of mass media and video. Hyperreality of mass media is the transformation of the existing reality in the space of information culture, which makes it possible to determine its surface as a hypersurface. Thus, the visual image acquires signs of virtual transformation, which arises in the space of super complex computer technologies.

It is important that exactly the topological equipment adds little to the aesthetic qualities of the visual image of the cyberspace. And no matter how much we talk about the topological space as the invariance itself, and moreover, the identity of the image and the surface, it is still the same exhilarated, harmonic dimension, which is bound with singularity and elementarism. But it is important that the hypersurface becomes a definite architectural thesaurus, which helps to understand that there is something extremely important, which means the architecture of the present as a division of territories. The hypersurface is a virtual means of transcending all boundaries of the architectural space but in the context of the topological dimension.

The visual experience that comes in architecture differs from the visualization of the perspective type of the Renaissance. On the contrary, it is an immanent visualization that does not belong to the viewer but belongs to the object itself. The object looks like an optical reality on a computer, and only then in the real space.

This is the inversion of the Optical Code of the Renaissance. Optical visibility is very similar to the eclecticism of the nineteenth century because it is actually a developed code of the Renaissance architecture, brought to its final ornamental rubicon. It seems that the "electronic baroque" is a completely different reality that does not fit into the space of the subject and the subjectivity as such belongs, first of all, to the object. If so, then the space itself becomes an object-given reality, which in turn needs its own subject.

I. Dobritsyna writes: "The use of computers as a mechanism for high abstraction in order to invent a new design strategy attracts the concept of dynamic organization and production of various distinctions, which are architectural and become a part of a real project practice. The shift from the Cartesian order to the topological geometry allowed to comprehend the complex and dynamic side of the object, involving a plurality of new concepts such as power fields, vectors, bending, etc. Those processes of professional thinking and practice that are evaluated as deep-endogenous are also changing. That is, these are the phenomena that should be correlated with the fundamental internal ideals of the profession, which determine the next evolutionary development strategy. There is a review of established and approved ascending concepts, which are more or less suitable for the definition of changes and representations of architectural practice. The architect works not only in the abstract three-dimensional space of the system of form-making. The architect can create effects of topological constructions. The poetics and aesthetics of the spatial categories system are changing" [2, 298].

All these well-marked changes speak not so much. First of all, the project activity, which is striking by its unpredictability and exogenous nature, does not have a sufficiently substantiated and clear conceptual platform that it possessed even in the period of futurological development of architecture, or in the period of deconstructivism.

The consequences of the computer revolution are unpredictable. That is, conceptualization itself, categorization and certain institutionalization of the concepts of both form-making and the design process are formed as a certain metaphorical symbolism or mythological synthesis, which resembles the process of synesthesia - the psychological re-coding of the data of exteroception, interoception, and proprioception [5]. That is, the architectural theory has been trying either to subjectivize, that is to turn the project into a volitional impulse, or to object and submit it as an analog of the creative power of biological or bionic systems.

Again, we refer to the statements of I. Dobritsyna: "Computer technology affects modern culture as a whole. Using the vocabulary of new science, one should consider that they are embedded precisely at that point of the beginning and end of the "loop with feedback", which passes through the whole culture. Such a loop, as somewhat integral, penetrates into the culture more and more and captures it with the help of the latest technologies. The rate of growth and expansion of new techniques depends on the speed of assimilation of technology in general, the 
degree of their inclusion in the cultural context. Active assimilation of all this news by the user of the most diverse categories and various fields of activity even nowadays is creating the preconditions for a qualitative transformation of culture. Undoubtedly, the composition of modern techniques lies in the weight of its evolution" [2, 303].

One can agree with this metaphorical definition, but the curve (loop) itself, drawn by I. Dobritsyna, strongly resembles the curve of Gilles Deleuze, and even more resemblance there is with the curve of G. Völflin. That is, we have the same "S" -like bend, we have the dialectic of denial, an expanded phrase or a rhythmic pattern, which suggests that a particular event is developed as a reflection, transformation and as the next generalization. All these signs are simple form-making intentions. They move from culture to culture, from one vocabulary to another, give birth to various lexemes and give rise to various discourses.

However, it is important to understand that it is the computer and computer technologies that allow non-linear modeling. They give an opportunity to move away from the topology of grids, lattices, the topology of Euclidean geometry, and to put in the computer a completely different architectural guideline - the nonlinear structure that is characteristic of living systems, in the development of the cell, and then, basing on these living systems, simulate architectural space. This is not a simple move, but it is interesting as a model cyber-computer space that creates certain artifacts of the design process.

It is important to note here that such works as Peter Eisenman's Aronoff Center, Daniel Libeskind's Jewish Center and Frank Gehry's Guggenheim Museum in Bilbao have been processed on the computer. Moreover, computer technology has identified $95 \%$ of the external form that we perceive. There is an interesting question - how much the artist or architect depends on computer technology? It cannot be answered unequivocally. It seems that Peter Eisenman is such an independent person that the computer could not dictate the conditions of form-making creativity to him. Using the computer capabilities, he only corrected, moreover, scanned the visual image and those constructive allusions, which he saw as form-making. After all, the paradigm of the continual and discrete space, imposed on each other, remains the author's model. The leader, of course, is the architect, but the computer helps to bring the idea to the last point of understanding and vision of the project space, which is already canonical or nominally designated as the topology of nonlinear space.

Frank Gehry in the project of the Guggenheim Museum also used computer simulation as well as the layout of space in the volume. It is important to note that the most up-to-date technologies related to computer technology are an indirect mechanism one way or another. After all, the bottom line is that computer reality or computer technologies from the scope of means move into the scope of the goal, become purposeful, acquire signs of paradigm synergistic reality. That is, the visual virtual field of an architectural image becomes so active that it leads to excessive decisions. We should ask the question if this transition is provoked by techno-culture. It is provoked, in general, by architecture. All signs of virtualization of the architectural space suggest that modern architecture is impossible without active means of information transformation. If it existed beyond all realities of computer technology, it would be completely different.

After all, we must clearly outline the scope of computer technology as a sphere of means. Computer technology is a means related to cyberspace, a computer means allows you to extend the ranges of the project space. After all, they (ranges) expand so much that all that we are accustomed to see as the objects of the architect's work, that is paper and drawings, disappear.

The turn, which took place in architecture as a negation of the Cartesian system of the metrological space topology, makes the structure of the field, plateau, rhizomes, and others a priority. You can interpret these processes differently - either in the progressive, or in the degradation dimension, since one way or another the innovations are related to the fact that there is an understanding of the procedural dimensions of design in architecture as large, super-complex systems that are bound with the universe, the planet, with the anthropomorphic space in general, with the microcosm and with those deep, relevant design realities that combine microcosm and macrocosm. It seems that the technics and technology of an architect's computer-aided designing allow you to see the new opportunity, which is linked either with the genetic algorithm, or with population thinking, or with intensities as a synergistic perception of space and topological thinking. These are the figures of the same design reality, the architect's reflections that arise with the help of a computer.

Cyberspace unfolds opportunities and the implementation language of project tasks is not always authentic ways. This is understood by the designer, but nobody is pursuing authenticity, and nobody is trying to repeat fully and completely the reality that occurs in the cell space or in the space of the Universe. On the contrary, everyone is interested in the space of allusions, or the space of the metaphorical reality that creates this experiment. The fact is that man-made civilization affects not only the architecture but also the person themselves. In culture, two development vectors are formed simultaneously. They are multi-directional and antagonistic in their direction. Together with the enthusiasm about technomorphic objects, at the same time, there is a conscious containment of the cyber-reality development.

The technical boom generates a number of technosystems that generate anti-systems, and there are binary oppositions that transform the design space into a variegated fabric of the legitimization of aesthetic priorities. This is a complex process that has not yet been determined or defined, but it says about anthropology preservation, that the anthroposphere should be both a biosphere and a noosphere where high technology is used.

Analyzing the current state, P. Virilio defines the development of technologies as follows: "The development of technologies, the total war, contributed to the transfer of intelligence to the systems that eventually became autonomous and marginalized, pushed themselves away from political and scientific power. From here goes the shift 
of philosophical thinking to the scientific, which is transformed again into a pure system, not to say worse - in the Great Automat. There was the automation of thought and computers became the symbol of that. The dead and living memory of poems is a monument to the death of philosophy. Of course, the bulk of the decisions are perceived statistically, by the machine way. At the same time, the state figures of the past were guided by intuitions, an insight that can be compared with the inspiration of philosophers and musicians" [7, 136].

That is, positivism as a direction, a way, a means, if it becomes a mega-system or mega-structure it eliminates both philosophy and culture. It seems that these problems are becoming a problem of the humanitarian boom of the present, or a problem that is marked as a problem of the threat of anthroposociogenesis itself in European culture [6]. It is especially important that the complexity of those systems that surround a person is growing. The man is already drawn into this complicated reality and does not see it in that dimension, where it has some simple and humane affirmations. If a person forgets that they exist, then they immediately become an automaton, that is, they are drawn into the stream of automation of the mind. There is a problem of new ethics, aesthetics, and philosophy. All this prompts to understand the design process in the context of the culture of the present, and architecture - as a separate cultural and historical reality.

One can assume that never before there has been the problem of a person-artist, which is not a problem of architecture or a problem of design but is a problem of culturology and anthropology as a whole. The humanity of an architectural image is under threat. Instead of a man-friendly environment, an excessive, illusory, changing world of mirroring is being formed. The forms of architecture over-represent their digital realities. New features are emerging from the practice of immersing of the architecture into the virtual reality, cyber-realities of space and the world of unforeseen energies.

Scientific novelty and practical significance of the research. A detailed explanation of computer-aided formmaking in the architectural design of postmodernism is for the first time presented in this work. The notion of "hypersurface" is specified and extended. The role and place of the computer which is transformed into an element of the paradigmatic and synergetic reality by means of which the transfer of intelligence occurs are determined.

Conclusions. As a result of the differentiation and analysis of the concepts of computer-aided form-making, applied in the architectural design of postmodernism, the following assumptions can be made: 1 ) the hypersurface is created as a space that does not divide, but rather encompasses, at the same time there is unification of the avantgarde and the ordinary system in the general human culture; 2 ) the computer originally being the proper factor of the design process as an exteriorly defined instrument of interpretation becomes a computer reality and acquires characteristics of paradigmatic and synergetic reality; 3) automation of thought takes place, with computers becoming its symbol; moreover, the transfer of intelligence to the systems occurs, and this is a question of the culture of creativity. It is impossible to get rid of it, but an architect or a designer still remains the creator and original source.

\section{תimepamypa}

1. Авдеева В.В. История зарубежного искусства. Архитектура XX века. Москва : Юрайт, 2018. 112 с.

2.Добрицына И.А. От постмодернизма - к нелинейной архитектуре. Москва : Прогресс-Традиция, 2004. 416 с.

3. Игнатьева И.Ф. Антропология техники: Человек как субъект мира техники. Екатеринбург : Изд-во Уральского ун-та, 1992. 130 с.

4. Легенький Ю.Г. Культурология изображения (опыт композиционного синтеза). Киев : ГАЛПУ, 1995. 412 с.

5. Легенький Ю.Г. Об архитектуре (очерки теории дизайна интерьера). Киев : Изд. центр КНУКиМ, 2005. 692 с.

6. Моисеев И.И. Универсум. Информация. Общество. Москва: Устойчивый мир, 2001. 199 с.

7. Рыклин М. Великий Автомат. Беседа с Полем Вирилио. Деконструкция и деструкция : беседы с философрами. Москва : Логос, 2002. C. $124-138$.

8. Хасиева М.А. Концепция постмодернизма в философии метаболизма К. Курокавы. Гуманитарный вектор. 2018. № 13 (3). С. 75-83.

9. Эстетические ценности предметно-пространственной среды / под. ред. А.В. Иконникова. Москва : Стройиздат, 1990. 335 с.

10. Perrella S. Hypersurface Theory: Architecture \& Culture. Architectura \& Design. 1998. № 68 (5/6). C. 7-15.

\section{References}

1. Avdeeva, V.V. (2018). History of foreign art. The architecture of the XX century. Moscow: Yurayt [in Russian].

2. Dobritsyina, I.A. (2004). From postmodernism to non-linear architecture. Moscow: Progress-Traditsiya [in Russian].

3. Ignateva, I.F. (1992). Anthropology of technology: Man as a subject of the world of technology. Yekaterinburg: Izdatelstvo Uralskogo universiteta [in Russian].

4. Legenkiy, Yu.G. (1995). Image culture (experience of compositional synthesis). Kyiv: GALPU [in Russian].

5. Legenkiy, Yu.G. (2005). About architecture (essays on the theory of interior design). Kyiv: KNUKiM Publishing [in Russian].

6. Moiseev, I.I. (2001). Universum. Information. Society. Moscow: Ustoychivyiy mir [in Russian].

7.Ryiklin, M. (2002). Great Automaton. Conversation with Paul Virilio. In Deconstruction and destruction: Conversations with philosophers (pp. 124-138). Moscow: Logos [in Russian].

8. Hasieva, M.A. (2018). The concept of postmodernism in the philosophy of metabolism K. Kurokawa. Gumanitarnyiy vektor, 13 (3), 75-83 [in Russian].

9. Ikonnikov, A.V. (Ed). (1990). Aesthetic values of the subject-spatial environment. Moscow: Stroyizdat [in Russian].

10. Perrella, S. (1998). Hypersurface Theory: Architecture \& Culture. Architectura \& Design, 68 (5-6), 7-15 [in English]. 